\title{
Financial Sector Reforms in India: Implications for Banking and Taxation
}

\author{
Sandeep Jain*
}

\begin{abstract}
Financial sector reforms in India have formed an important component of the overall economic reforms process initiated in the early 1990s. These reforms have followed a well calibrated approach. The general approach to financial sector reforms has been a transparent, collaborative and consultative process aimed at resolving many possible dilemmas. While the scope of financial sector reforms is immense, this paper focuses on the implications of these reforms for banking and taxation. In general, both these areas have witnessed significant transformation from reforms in terms of switchover to international best practices, enabling legislation, effective monitoring and supervision, and technology.
\end{abstract}

Keywords: Financial sector reforms, Banking sector, Tax reforms, Development.

\subsection{Introduction}

A well-functioning financial system is a pre-requisite for the pursuit of economic growth with stability. The core function of a financial system is to facilitate smooth and efficient allocation of resources from savers to the ultimate users. The financial infrastructure contributes to the effective functioning of institutions and markets and thereby to stability. Hence, it serves as the foundation for adequate access to financial services and sustained financial development.

The relationship between finance and development has been a crucial subject of public policy for long. As early as in the 19th century, a number of economists stressed the importance of financial development for the growth of an economy. The banking system was recognised to have important ramifications for the level and growth rate of national income via the identification and funding of productive investments. This, in turn, was expected to induce a more efficient allocation of capital and foster growth. A contrary view also prevailed at the same time suggesting that economic growth would create demand for financial services.

* FCA, Chartered Accountant, Senior Partner - SKC, Delhi. 
This meant that financial development would follow growth more or less automatically. In other words, financial development could be considered as a byproduct of economic development.

\subsection{Towards Financial Activism}

The world of finance has changed markedly over the last 30 years or so. The change has been brought about by a number of events and circumstances. The growing dissatisfaction with the working of the fixed exchange rate system during the 1960s led many countries, especially of the industrialised world, to adopt a floating exchange rate system by the early 1970s. There was also a growing realisation that for achieving sustained growth with stability, it would be necessary to have freer trade, liberalised external capital movements, and a relatively flexible use of domestic monetary policy. With trade being subject to multilateral negotiations, industrialised countries and some of the emerging market economies took steps to liberalise capital movements across countries since about the middle of the 1970s. Simultaneously, efforts were made to remove distortions in the domestic financial sector through elimination or containment of reserve requirements and interest rate regulations. These initiatives coincided with the rapid technological improvements in electronic payments and communication systems. The interaction among these factors helped the process of internationalisation of financial markets.

Under the impact of economic liberalisation, the industrialised countries, as a group, improved their relative economic position in the world economy, and posted high growth rates in the 1980s and thereafter. This experience has confirmed the release of growth impulses following financial liberalisation.

Developing countries, on their part, have been adopting, since the early 1980s, marketoriented strategies of financial development, partly supported by international financial institutions, and partly to avail of the large pool of resources available in international financial markets. They either dismantled or sharply contained financial repression and undertook financial reforms with a view to enhancing allocative efficiency and competitiveness. Financial development required the deepening and widening of the existing financial markets as well as the introduction of new products and instruments to cater to the needs of savers and investors.

Financial development depends on market-based regulatory framework and incentives (disincentives) that promote market discipline. If market discipline is not well-understood or not complied with, there would arise possibilities of inefficiencies and/or volatilities in asset prices and capital movements. Financial stability, therefore, is a pre-requisite for sustained financial development which in turn would impact growth rate positively. 


\subsection{India's Approach to Financial Sector Reforms}

Financial sector reforms in India have formed an important component of the overall economic reforms process initiated in the early 1990s. These reforms have followed a well calibrated approach. The general approach to financial sector reforms has been a transparent, collaborative and consultative process aimed at resolving many possible dilemmas. The reform process itself was characterised by caution with a tilt towards preserving stability, careful sequencing of measures, mutually reinforcing monetary measures and ensuring consistency and complementarity with other policies.

Further, reforms in the financial markets have been undertaken within the overall monetary policy framework and in co-ordination with reforms in the money and foreign exchange markets. Many of the major reforms have been implemented in phases, allowing for transition so as not to destabilise market conditions or any group of participants or the financial system in general.

In the context of maximising benefits of financial integration and minimising the risks, the link with the real sector cannot be ignored. In India, reforms in the financial sector started early in the reform cycle which imparted efficiency and stability to the real sector. The financial sector can add competitive strength and growth if reforms in the financial and real sectors keep apace. A major agenda for reform at this juncture for India, given the impressive all-round confidence in the economy, relates to the structure and functioning of institutions and in particular lowering the high transaction costs prevalent in the system. There are several dimensions to the transaction costs-ranging from legal provisions, the judicial system and procedures to attitudes.

The policy of gradualism that has been followed by India focuses on evolution of appropriate institutional framework and the sequencing of reforms based on the experience gained so far. The sequencing and pace of reforms are also vital to safeguard monetary and financial stability and avoid reversals. The issues in this context include: (a) whether bank-based or market-based system of development should be adopted, (b) order of sequencing of reforms of various segments of the financial market to be followed, and (c) whether or not capital account liberalisation should precede domestic financial market reform.

\subsection{Financial Regulation and Supervision}

The quality of financial regulation and supervision as well as of information and the legal system are important for reaping the benefits of globalisation. Hence, enactment of enabling legislation has been a priority area of the reforms. The Board for Financial 
Supervision (BFS) was constituted in 1994, with the mandate to exercise the powers of supervision and inspection in relation to the banking companies, financial institutions and non-banking financial companies.

With the switchover to international best practices on income recognition, asset classification and provisioning, the problem of non-performing assets (NPAs) assumed critical importance. It was widely perceived that the level of NPAs in India was high by international standards. The problem needed to be tackled urgently and from different fronts. A menu approach has been adopted to tackle this major constraint confronting the banking sector. These policy measures have resulted in reduction in gross NPAs in the banking system.

The need for monitoring and supervising becomes even more important systemically with the opening up of the economy. Thus, the prudential regulations were fortified by reorientation of on-site inspections and introduction of off-site surveillance. The focus of inspection has shifted from ensuring appropriate credit planning and credit allocation under a closed economy framework to assessment of the bank's safety and soundness and to identify areas where corrective action is needed to strengthen the institution and improve its performance.

In view of the growing liberalisation of the external sector and international banking by banks in India, monitoring of the cross-border flow of funds has assumed importance. RBI now compiles and disseminates international banking statistics (IBS) on the lines of the reporting system devised by the Bank for International Settlements (BIS). The locational banking statistics (LBS) provide the gross position of international assets and international liabilities of all banking offices located in India. They report exclusively banks' international transactions including the transactions with any of their own branches/subsidiaries/joint ventures located outside India.

\subsection{Migration to Basel II Norms}

The banking systems worldwide have/are migrating to the Basel II regime. The Basel II framework is expected to promote adoption of stronger risk management practices by banks to address major risks. In the context of the Indian banking system's transformation to Basel II, some issues have arisen.

Though concurrent efforts are underway in India to refine and upgrade financial information monitoring, data dissemination and data warehousing in various banks, the magnitude of the task appears to be difficult as there are a large number of commercial banks in India, which are at various levels of development. As the new system is resource-intensive requiring large database and strong information technology architecture, it places heavy demand on banks and the regulator to improve their 
information base through appropriate tools. Implementation of various simplified approaches requires preparation on the part of the banks, banking regulator and the rating agencies. Inadequate historical data in conjunction with associated cost of developing and maintaining such data may also influence the speed of migration to advanced approaches of risk measurement under Basel II. As the implementation of Basel II gathers momentum, several banks in India may need additional capital to provide for capital charge for market risk and operational risk.

Despite these challenges, it appears that Indian banks would be able to migrate to Basel II norms as India has chosen to adopt simpler options for the transition initially. The RBI has adopted a consultative and participative approach for both designing and implementing the transition process. Many pubic sector banks and old private sector banks have already prepared a roadmap for migrating to Basel II.

\subsection{Technological Solutions for Financial Services}

Most of the initiatives regarding technology are aimed at providing better and more efficient customer service by offering multiple options to the customer. The death of distance, which is a by-product of technology, has become a reality in the banking sector. Technology is also playing a key role in banks' strategy for gaining a competitive edge.

Many banks have commenced the process of setting up core banking solutions, which are at various stages of implementation. While such systems are already in place in respect of new private sector banks, a few old private sector banks and public sector banks are also quickly moving to set up such processes. This would benefit the customer in the banking sector. Computerisation of the business of banks has been receiving high importance. The public sector banks have already crossed the 70 percent level of computerisation of their business. The directive from the Central Vigilance Commission (CVC) to achieve 100 percent computerisation has resulted in renewed vigour towards computerisation of branches.

Networking has been receiving focused attention by banks. This activity is also being monitored by the RBI. Most banks have their own corporate networks to facilitate inter-branch and branch-controlling office communication in an electronic mode. Interbank and inter-city communication takes place through the Indian Financial Network (INFINET). As part of the INFINET, the terrestrial lines have been augmented to provide for increased data transfer capabilities. All these have resulted in the dependence of banks on network-based computing which has benefited the customer.

INFINET also provides for safe and secure transmission of electronic messages with the use of public key infrastructure (PKI) which has the legal backing of Information Technology Act, 2000. It also provides for messages to flow in a structured environment, using the structured financial messaging solutions (SFMS), which provides for inter- 
operability of messages so that straight through processing (STP) is achieved.

Another major development witnessed in recent years is the growth in multiple delivery channels to customers such as internet-based banking, mobile banking and anywhere banking. This has benefited the customers and the banks alike. While customers have now a wide variety of options to choose from, banks have been able to reduce costs which have had a positive impact on their profitability.

These developments have, however, also posed certain challenges. In a world where geographical barriers are losing significance, it is essential that security is given prime importance in a transnational scenario where large sums of money are at stake. While the challenges relating to physical security could be confronted with relative ease, the position is much more complicated in respect of IT security. The RBI has, therefore, provided guidelines on information system (IS) security as also IS audit which banks can use for their benefit. These are generic in nature and do not have any prescriptive tones.

\subsection{High Level Committee on Financial Sector Reforms, 2008}

With a view to outlining a comprehensive agenda for the evolution of the financial sector-indicating especially the priorities and sequencing decisions which the Government of India must keep in minds - a High Level Committee on Financial Sector Reforms was set up by the Planning Commission of India in August 2007. The Committee (Chairman: Raghuram G. Rajan) submitted its report in September 2008, and made the following main recommendations:

1. Allow more entry to private well-governed, deposit-taking small finance banks.

2. Liberalise the banking correspondent regulation so that a wide range of local agents can serve to extend financial services. Use technology both to reduce costs and to limit fraud and misrepresentation.

3. Offer priority sector loan certificates (PSLC) to all entities that lend to eligible categories in the priority sector. Allow banks that undershoot their priority sector obligations to buy the PSLC and submit it towards fulfilment of their target.

4. Sell small under-performing public sector banks, possibly to another bank or to a strategic investor, to gain experience with the process and gauge outcomes.

5. Create stronger boards for large public sector banks, with more power to outside shareholders (including possibly a private sector strategic investor), devolving the power to appoint and compensate top executives to the board.

6. After starting the process of strengthening boards, delink the banks from additional government oversight, including by the Central Vigilance Commission and Parliament, with the justification that with government-controlled boards governing the banks, a second layer of oversight is not needed. 
7. Be more liberal in allowing takeovers and mergers, including by domestically incorporated subsidiaries of foreign banks.

8. Free banks to set up branches and ATMs anywhere.

\subsection{Reforms and Taxation}

It may be recalled that the external payments crisis of 1991, which led to the initiation of economic reforms in India, was the result of deteriorating fiscal situation during the latter half of 1980s. This period was marked by high and persistent fiscal deficits, accompanied by large revenue deficits. This had led to a significant enlargement of Government borrowings from financial intermediaries and increased financing of Government deficit through automatic monetisation which aggravated price rise. When the Indian economy faced an unprecedented macroeconomic crisis in 1991, fiscal consolidation constituted a major objective of the policy response. This consolidation was to be achieved through reduction in the size of budget deficit and public debt in relation to GDP. For this purpose, it became necessary to (a) enhance tax and non-tax revenue, (b) curtail current expenditure growth, (c) restructure public sector undertaking, including disinvestment, (d) improve fiscal-monetary co-ordination, and (e) deregulate financial system.

Apart from these reforms aimed at fiscal consolidation, a number of institutional measures were also taken during the 1990s. Public sector restructuring and disinvestments were undertaken with a view to increase the efficiency of the public sector undertakings and also to provide additional resources to the Government. The need for improvements in budgetary practices led to the enactment of the Fiscal Responsibility and Budget Management (FRBM) Act, 2003 which ushered the Indian economy in an era of fiscal consolidation based on fiscal policy rules.

The financing of fiscal deficit is another area, which has undergone significant changes in the post-reform period. With the discontinuation of ad hoc 91-day Treasury Bills in April 1997, automatic monetisation of deficits was eliminated. Greater reliance on borrowing at market-related interest rates since 1992 led to a substantial lowering of statutory pre-emption of institutional resources for the Government. This has also facilitated development of the market for Government securities, which has witnessed remarkable changes since the latter half of the 1990s.

Restructuring of the tax system has constituted a major component of fiscal reforms initiated since 1991. The main focus of the tax reforms has been on simplification and rationalisation of both direct and indirect taxes with the objective of augmenting revenues and removing anomalies in the tax structure. Tax reforms since 1991 have 
brought the tax system much closer to international tax practices. Government's concern with tax reforms is reflected in the appointment of a number of committees in recent years to review the tax system. These have, inter alia, included:

- Tax Reforms Committee (Chairman: Raja Chelliah), 1991.

- Advisory Group on Tax Policy and Tax Administration for the Tenth Plan (Chairman: Parthasarathi Shome), 2001

- Inter-ministerial Working Group on Customs Tariff (Chairman: Arvind Virmani), 2002

- Task Force on Direct Taxes (Chairman: Vijay Kelkar), 2002.

- Task Force on Indirect Taxes (Chairman: Vijay Kelkar), 2002.

- White Paper on State-Level Value Added Tax (Chairman: Asim Kumar Dasgupta), 2005.

- Rationalisation of Customs and Excise Duties on Edible Oils and Oilseeds (Chairman: Ashok Lahiri), 2006.

In fact, tax reforms are a part of the package to liberalise and globalise the Indian economy. The post-1991 period has witnessed a sharp decline in the rates of income tax, excise duty and customs tariff. The theory that high rates of duty lead to higher revenue collection has been discarded in favour of lower rates with fewer exemptions and concessions.

Tax reforms undertaken by the Government in tandem with economic reforms since 1991 have helped to rationalise and simplify the tax system considerably. The rates have been moderated and many exemptions and concessions have been weeded out.

\subsection{Achievements of Financial Sector Reforms and Areas of Concern}

Financial sector in the Indian economy since the early 1990s has undergone a transformation towards a vibrant, competitive and diversified system, with a multiplicity of financial institutions having different risk profiles intermediating in various segments of the market spectrum. The evolution of the Indian financial system from somewhat of a constricted and an undersized one to a more open, deregulated and market oriented one and its interface with the growth process are the major areas of reforms still underway.

The financial system has exhibited considerable dynamism in recent years. The system today is varied, with a well-diversified structure of financial institutions, financial companies and mutual funds. The setting up of some specialised financial institutions and refinance institutions has provided depth to financial intermediation outside the banking sector. These developments, coupled with increased financial market 
liberalization, have enhanced competition. A number of existing financial institutions have diversified into several new activities, such as, investment banking and infrastructure financing, providing guarantees for domestic and offshore lending for infrastructure projects.

Rapid expansion of non-banking financial companies (NBFCs) has taken place, providing avenues for depositors to hold assets and for borrowers to enhance the scale of funding of their activities. Various types of NBFCs have provided varied services that include equipment leasing, hire purchase, loans, investments, mutual benefit and chit fund activities. More recently, NBFCs activity has picked up in the area of housing finance.

Financial development is also reflected in the growing importance of mutual funds. In the 1990s, they enabled sizable mobilisation of financial surpluses of the households for investment in capital markets. Capital markets themselves have become an important source of financing corporate investments, especially after firms were permitted to charge share premium in a flexible manner.

An understanding of the organisational structure of markets for financial assets is vital for knowing the limitations and prospects with regards to efficiency, integration and stability. Financial markets in India comprise, in the main: the credit market, the money market, the foreign exchange market, the debt market and the capital market. Recently, the derivatives market has also emerged. With banks having already been allowed to undertake insurance business, bancassurance market is also likely to emerge in a big way.

Most of the financial markets were characterised, till the early 1990s, by controls over the pricing of financial assets, restrictions on flows or transactions, barriers to entry, low liquidity and high transaction costs. These characteristics came in the way of development of the markets and allocative efficiency of resources channelled through them.

The initiation of financial sector reforms in the early 1990s was essentially to bring about a transformation in the structure, efficiency and stability of financial markets, as also an integration of the markets.

In spite of the significant improvements in the banking industry as a result of reforms, several challenges lie ahead, the most important being the need to bring down the NPAs. Commercial banks continue to face the problem of non-performing assets (NPAs), attributable, inter alia, to factors such as weak debt recovery mechanism, nonrealisation of collateral and poor credit appraisal techniques. Policy measures have not yielded the desired results. The recent enactment of the Securitisation and Reconstruction of Financial Assets and Enforcement of Security Interest Act, 2002 has 
increased the momentum for the recovery of NPAs. However, banks need to intensify their efforts to recover their overdues and prevent generation of fresh NPAs.

Co-operative banks constitute an important segment of the Indian banking system. They have an extensive branch network and reach out to people in remote areas. They have traditionally played an important role in creating banking habits among the lower and middle-income groups and in strengthening the rural credit delivery system. Unfortunately, financial reforms have not impacted the functioning of co-operative banks. Since the introduction of reforms, there has been very little perceptible improvement in either stability or efficiency of co-operative banks. In particular, the asset quality and profitability of cooperative banks has shown some deterioration in the reform period. Positive impact of reforms, as has been witnessed in the case of commercial banking sector, may take longer to get manifested for co-operative banks given the late start of the reform process in this sector.

Financial institutions, which constitute an important source of funds for the commercial sector, have been losing ground fast. The situation has come about as a result of the distinction between development and commercial banking getting blurred, high cost of funds and asset-liability mismatches. With reforms in the financial sector, the facility of low cost funds under long-term operations funds, funds from bilateral and multilateral agencies and bond issues under statutory liquidity ratio is no more available. Now the financial institutions are raising funds at market-related rates of interest. The Reserve Bank of India (RBI) has been advising financial institutions to chart a path for their evolution into universal banks. The merger of ICICI with the ICICI Bank was approved by the RBI in April 2002.

Competitive pressures as well as prudential regulatory requirements have made banks risk-averse, preferring their investment in relatively risk-free gilt instruments. The behaviour and strategies of bank business would need to change from the present so that they can factor in their own risk assessment even while performing their core activities. There is a need to ensure long term finance to support development and growth in the economy, even as restructuring takes place through mergers and universal banking.

True, there has been a significant progress towards globalisation in the recent past in India, the extent to which the country is globalised is considerably low as compared with other emerging economies. This indicates not only the existence of enormous opportunities but also challenges in terms of transition from a non-entity to a major player in the global financial system.

\subsection{Summing Up}

To recapitulate, in the context of the balance of payments crisis of 1991, a 
comprehensive structural and financial sector reform process was initiated in India as recommended by the Committee on the Financial System (Chairman: M. Narasimham, 1991) which became the starting point for gradual deregulation of the financial sector and development and integration of various segments of the financial market. Measures were initiated to streamline functioning of the financial system to create a sound, competitive and efficient banking system capable of meeting the increasing challenges of liberalisation and globalisation.

A safe and sound financial sector is a prerequisite for sustained growth of any economy. Globalisation, deregulation and advances in information technology in recent years have brought about significant changes in the operating environment for banks and other financial institutions. These institutions are faced with increased competitive pressures and changing customer demands. These, in turn, have engendered a rapid increase in product innovations and changes in business strategies. While these developments have enabled improvement in the efficiency of financial institutions, they have also posed some serious risks. The regulatory and supervisory policies are, accordingly, being reshaped and reoriented to meet the challenge of containing systemic risks. In this changing milieu, the main challenge for the supervisors has been to maintain the stability of the financial system and, at the same time, provide sufficient flexibility to financial institutions so that they can respond effectively to the growing competition while taking advantage of business opportunities and technological developments.

With the liberalisation of financial markets, policy authorities in India have also had to contend with episodes of financial volatility as were witnessed in some East Asian countries. Recognising the strong complementarity between financial stability and macroeconomic stability, the operational settings for policies are being geared to dampen excessive volatility and the possible impairment of the ability of financial institutions to handle fluctuations in financial asset prices. Current macroeconomic and financial developments in the Indian economy highlight the evolving role of the financial sector in the functioning of the economy and the growing integration across financial markets.

Although the financial sector in India has grown fairly rapidly in recent years, in terms of the conventional metrics of financial deepening - such as a ratio of total financial claims or bank loans to GDP - India appears to be considerably behind other emerging markets. One of the most important gaps in our existing financial structure is the lack of a sufficiently large venture capital and angel investor community, which play important role in financing start-ups, especially in areas where technology is the key to success and risk capital is needed.

The financial sector in the Indian economy is undergoing a transformation towards a 
vibrant, competitive and diversified system, with a multiplicity of financial institutions having different risk profiles intermediating in various segments of the market spectrum. The development of banking is a critical element in the agenda of financial sector reforms in India. Financial sector reforms in India are by no means complete. Plans are afoot to modernise the financial system to make it compatible with best international practices. 